\title{
GABA Spillover from Single Inhibitory Axons Suppresses Low- Frequency Excitatory Transmission at the Cerebellar Glomerulus
}

\author{
Simon J. Mitchell and R. Angus Silver \\ Department of Physiology, University College London, London, WC1E 6BT, United Kingdom
}

\begin{abstract}
GABA type $B$ receptors $\left(\mathrm{GABA}_{\mathrm{B}}-\mathrm{Rs}\right)$ are present on excitatory terminals throughout the CNS, but surprisingly little is known about their role in modulating neurotransmission under physiological conditions. We have investigated activation of $\mathrm{GABA}_{\mathrm{B}}-\mathrm{Rs}$ on excitatory terminals within the cerebellar glomerulus, a structure where glutamatergic excitatory and GABAergic inhibitory terminals are in close apposition and make axodendritic synapses onto granule cells. Application of the $\mathrm{GABA}_{\mathrm{B}}-\mathrm{R}$ agonist baclofen depressed evoked mossy fiber EPSCs by $54 \%$ at $1 \mathrm{~Hz}$. The amplitude of miniature EPSCs recorded in tetrodotoxin was unchanged in the presence of baclofen, but the frequency was significantly reduced, indicating a purely presynaptic action of baclofen under our recording conditions. At physiological temperature $\left(37^{\circ} \mathrm{C}\right)$ presynaptic $\mathrm{GABA}_{\mathrm{B}}-\mathrm{Rs}$ were not tonically acti-
\end{abstract}

vated by spontaneous GABA release from Golgi cells, which fire at $\sim 8 \mathrm{~Hz}$ in slices at this temperature. However, tonic activation could be induced by blocking GABA uptake or by lowering temperature. $\mathrm{GABA}_{\mathrm{B}}-\mathrm{Rs}$ were activated at physiological temperature when Golgi cell firing was increased above the basal level by stimulating a single inhibitory Golgi cell input at $50 \mathrm{~Hz}$, suppressing the mossy fiber-evoked EPSC by $24 \%$ at $1 \mathrm{~Hz}$. Furthermore, glutamate release was selectively inhibited at lowfrequency mossy fiber inputs $(<10 \mathrm{~Hz})$ during Golgi cell stimulation. Our findings suggest that GABA spillover in the glomerulus modulates sensory input to the cerebellar cortex.

Key words: transmitter spillover; $G A B A_{B}$; heteroreceptor; presynaptic; glutamate; synaptic transmission
Presynaptic GABA type $B$ receptors $\left(\mathrm{GABA}_{\mathrm{B}}-\mathrm{Rs}\right)$ modulate synaptic transmission throughout the nervous system by altering the probability of transmitter release. $\mathrm{GABA}_{\mathrm{B}}$-Rs present on inhibitory terminals (autoreceptors) can be activated homosynaptically by GABA released from the same synapse (Deisz and Prince, 1989; Davies et al., 1991). GABA $\mathrm{B}_{\mathrm{B}}$-Rs are also found on excitatory terminals in brain regions where direct presynaptic and reciprocal inhibitory synapses are absent (Shepherd, 1998). Several studies have established that $\mathrm{GABA}_{\mathrm{B}}$-Rs on excitatory terminals in hippocampus and cerebellar cortex can be activated by spillover of GABA from interneurons (Isaacson et al., 1993; Dittman and Regehr, 1997; Vogt and Nicoll, 1999). Synchronous activation of many interneurons is likely during extracellular stimulation in these preparations so it is unclear whether GABA release from a single input or synchronous release from many inputs is necessary for heterosynaptic activation. Studying single inhibitory inputs is therefore important for assessing the extent to which presynaptic $\mathrm{GABA}_{\mathrm{B}}$ heteroreceptors are activated in vivo.

Heterosynaptic activation of presynaptic receptors requires spillover of transmitter. The distance over which transmitter can travel from the release site and activate receptors at other synapses is dependent on diffusion and the efficacy of transmitter uptake in the locality (Isaacson et al., 1993; Barbour and Häusser, 1997; Rusakov et al., 1999). Heteroreceptor activation is therefore likely to be strongly dependent on temperature, because uptake mechanisms have a large $\mathrm{Q}_{10}(\sim 3$; Wadiche and Kavanaugh, 1998). However, most of the experiments examining GABA spillover onto presynaptic heteroreceptors have been performed below body temperature $\left(26-33^{\circ} \mathrm{C}\right.$; Isaacson et al., 1993; Dittman and Regehr, 1997; Yamada et al., 1999; Aroniadou-Anderjaska et al., 2000). This

Received June 20, 2000; revised Sept. 13, 2000; accepted Sept. 18, 2000.

This work was supported by The Wellcome Trust, the European Union (BIO4CT98-0182), and the Medical Research Council (Research Studentship to S.J.M.). We thank Novartis Pharma for the gift of CGP35348 and David Attwell, David DiGregorio, Mark Farrant, Michael Häusser, Bernard Katz, and Tomoyuki Takahashi for comments on this manuscript.

Correspondence should be addressed to Dr. R. A. Silver, Department of Physiology, University College London, Gower Street, London, WC1E 6BT, UK. E-mail: a.silver@ucl.ac.uk.

Copyright (C) 2000 Society for Neuroscience $0270-6474 / 00 / 208651-08 \$ 15.00 / 0$ raises the question of whether the extrasynaptic concentration of GABA is sufficient to produce significant tonic and/or phasic activation of $\mathrm{GABA}_{\mathrm{B}}$-Rs on excitatory inputs at body temperature (Isaacson et al., 1993). The fraction of $\mathrm{GABA}_{\mathrm{B}}-\mathrm{Rs}$ occupied at physiological temperature is a key parameter because it influences glutamate release probability and thus determines the frequencydependent behavior of the synapse (Brenowitz et al., 1998; Brody and Yue, 2000; Kreitzer and Regehr, 2000). Quantifying the inhibition of EPSCs by synaptically released GABA is therefore an important prerequisite for inferring how presynaptic $\mathrm{GABA}_{\mathrm{B}}-\mathrm{Rs}$ modulate synaptic efficacy under physiological conditions.

We have examined activation of presynaptic $\mathrm{GABA}_{\mathrm{B}}$-Rs at excitatory mossy fiber-granule cell synapses in the cerebellum. This preparation has several advantages for investigating presynaptic modulation (Mitchell and Silver, 2000). The presynaptic elements that innervate granule cells form a glomerular structure that consists of a single large excitatory mossy fiber terminal and an inhibitory Golgi cell axon (Eccles et al., 1967; Jakab and Hámori, 1988). The whole structure, including the ends of the granule cell dendrites, are ensheathed in a glial coat (Jakab and Hámori, 1988) which may localize spillover of transmitter (Brickley et al., 1996; Wall and Usowicz, 1997; Rossi and Hamann, 1998; Mitchell and Silver, 2000). Each of the three to five granule cell dendrites is innervated by a different mossy fiber, and up to 50 different granule cells make synapses within each glomerulus (Eccles et al., 1967; Jakab and Hámori, 1988). The low density of mossy fibers and Golgi cells in the granule cell layer allow the activation of single inputs using local extracellular stimulation (Silver et al., 1996). Here we demonstrate that $\mathrm{GABA}_{\mathrm{B}}-\mathrm{Rs}$ on mossy fiber terminals are activated when single Golgi cell inputs are stimulated at physiological temperature $\left(\sim 37^{\circ} \mathrm{C}\right)$. Furthermore, we find that $\mathrm{GABA}_{\mathrm{B}}-\mathrm{Rs}$ depress EPSCs only when mossy fiber firing rate is low.

\section{MATERIALS AND METHODS}

Sagittal slices of cerebellum $(250 \mu \mathrm{m})$ were prepared from 12- to 13-d-old Sprague Dawley rats as previously described (Silver et al., 1998). The external recording solution contained (in $\mathrm{mm}$ ): 125 $\mathrm{NaCl}, 2.5 \mathrm{KCl}, 2 \mathrm{CaCl}_{2}, 1 \mathrm{MgCl}_{2}, 1.25 \mathrm{NaH}_{2} \mathrm{PO}_{4}, 26 \mathrm{NaHCO}_{3}$, and 25 glucose, $\mathrm{pH} 7.3$ when bubbled with $95 \% \mathrm{O}_{2}$ and $5 \% \mathrm{CO}_{2}$; $310 \mathrm{mOsm}$. All recordings were made at $36.5 \pm 0.1^{\circ} \mathrm{C}$ (range, 
$35-38^{\circ} \mathrm{C} ; n=41$ ) except where stated otherwise. We added $15 \mu \mathrm{M}$ bicuculline methobromide, $10 \mu \mathrm{M}$ D-2-amino-5-phosphonopentanoic acid (D-AP-5), $20 \mu \mathrm{M}$ 7-chlorokynurenic acid (Tocris Cookson, Bristol, UK), and $0.5 \mu \mathrm{M}$ strychnine to the perfusate to block $\mathrm{GABA}_{\mathrm{A}}$, NMDA, and glycine receptors. Baclofen (50-100 $\mu \mathrm{M})$ and CGP35348 $(500 \mu \mathrm{M})$ were added to activate and antagonize $\mathrm{GABA}_{\mathrm{B}}-\mathrm{Rs}$, respectively, and NO711 (50 $\mu \mathrm{M})$ was added to block GABA uptake. Recordings were made using an Axopatch 200B amplifier (Axon Instruments, Foster City, CA), and 7-10 M $\Omega$ micropipettes made from standard wall borosilicate glass. Some of the experiments in which $\mathrm{GABA}_{\mathrm{B}}$-Rs were activated pharmacologically were recorded with an internal solution containing (in $\mathrm{mm}$ ): $110 \mathrm{CsF}, 30 \mathrm{CsCl}, 10$ CsHEPES, 10 CsEGTA, $2 \mathrm{NaCl}$, and $2 \mathrm{MgATP}$, adjusted to $\mathrm{pH} 7.3$ with $\mathrm{CsOH} ; 290 \mathrm{mOsm}$. However, the majority were recorded with $140 \mathrm{CsCl}, 10 \mathrm{CsHEPES}, 10 \mathrm{CsEGTA}, 2 \mathrm{NaCl}$, and $2 \mathrm{MgATP}$, adjusted to $\mathrm{pH} 7.3$ with $\mathrm{CsOH} ; 290$ mOsm. This gave a reversal potential of $\sim 0 \mathrm{mV}$ for EPSCs and IPSCs. In experiments in which excitatory and inhibitory inputs were activated onto the same granule cell, a pipette solution with a chloride reversal potential of $-24 \mathrm{mV}$ was used (75 CsMethylsulphonate, $50 \mathrm{CsCl}, 10 \mathrm{CsHEPES}, 10$ CsEGTA, $2 \mathrm{NaCl}$, and $2 \mathrm{MgATP}$ ) allowing EPSCs and IPSCs to be viewed separately. Golgi cell and mossy fiber axons were stimulated using patch pipettes filled with recording solution and driven by isolated constant voltage devices (Digitimer, Welwyn Garden City, UK). A single fiber was identified with minimal stimulation on the basis of an all-or-none postsynaptic current elicited by a stimulus of graded intensity and the presence of a single peak in the average current. The stimulation voltage was set $5-10 \mathrm{~V}$ above threshold to ensure reliable fiber stimulation (Silver et al., 1996). Data were acquired at $10-25 \mathrm{kHz}$ after low-pass filtering at $2-5 \mathrm{kHz}$ (4 pole Bessel filter) using Axograph 4 software (generous gift of John Clements, Australian National University, Canberra, Australia) and an Instrutech ITC-18 interface (Instrutech, Port Washington, NY). Miniature EPSCs were detected with a template detection method implemented in Axograph (Clements and Bekkers, 1997). The time stability of synaptic currents was assessed using Spearman rank order correlation analysis. Means are expressed \pm SEs. Groups were compared using a paired two-tailed Student's $t$ test except where stated. Results were considered significant at $p<0.05$.

\section{RESULTS}

\section{Pharmacological activation of $\mathrm{GABA}_{B}-\mathrm{Rs}$ on mossy fiber terminals}

We first established whether presynaptic $\mathrm{GABA}_{\mathrm{B}}$-Rs were present on mossy fiber terminals by using a conventional pharmacological approach. Application of the $\mathrm{GABA}_{\mathrm{B}}-\mathrm{R}$ agonist baclofen $(100 \mu \mathrm{M})$ reduced the mean amplitude of the evoked non-NMDA receptormediated EPSC by $54 \pm 5 \%$, in a reversible manner at $37^{\circ} \mathrm{C}(1 \mathrm{~Hz}$, $p<0.001, n=12$; Fig. $1 A, B)$. The coefficient of variation $(\mathrm{CV}$; $\mathrm{SD} / \mathrm{mean}$ ) of the EPSC increased in the presence of baclofen $(200 \pm 20 \%$ of control, $p=0.002, n=12$; Fig. $1 B)$, consistent with the EPSC depression being mediated, at least in part, by a reduction in glutamate release onto the granule cell. We investigated the locus of the $\mathrm{GABA}_{\mathrm{B}}-\mathrm{R}$ action further by examining the effect of baclofen on miniature currents recorded in the presence of tetrodotoxin $(0.5 \mu \mathrm{M})$. Under our experimental conditions, using a cesium-based internal solution to block postsynaptic potassium currents, the mean amplitude of miniature EPSCs in the presence of baclofen was similar to control $(p>0.05, n=6$; Fig. $1 C)$, but the miniature frequency was significantly reduced $(50 \pm 12 \%, p=0.01$, $n=6$; Fig. $1 D$ ), as expected for a purely presynaptic mechanism.

We examined the effect of presynaptic $\mathrm{GABA}_{\mathrm{B}}-\mathrm{R}$ activation on the EPSC over a range of mossy fiber stimulation frequencies that were similar to the firing rates observed in vivo (van Kan et al., 1993). Under control conditions the steady-state amplitude of the evoked mossy fiber EPSC declined as the stimulation frequency increased (Fig. $2 A, B$ ). In the presence of a saturating concentration of baclofen (100 $\mu \mathrm{M}$; Takahashi et al., 1998) the frequency dependence of the EPSC was flattened because of selective depression at

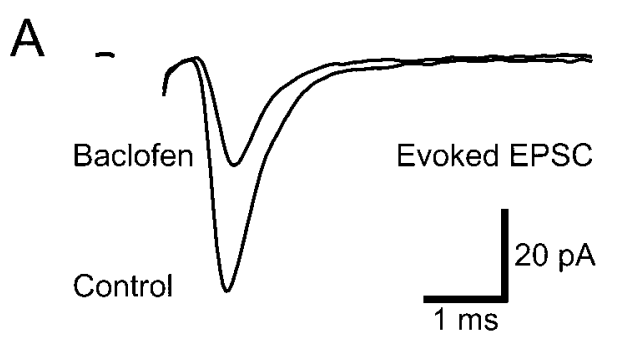

B
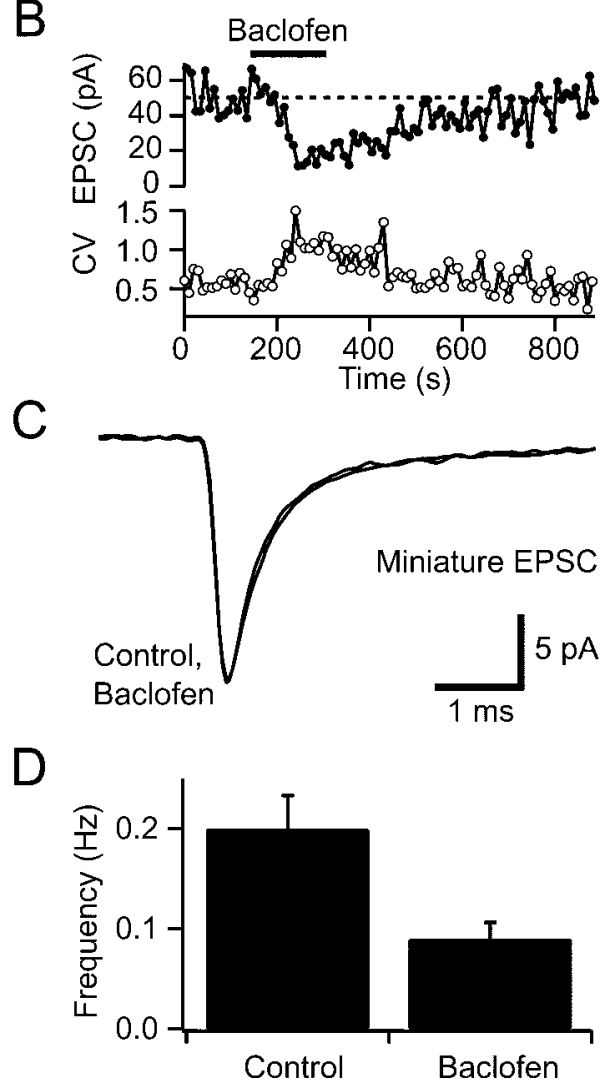

Figure 1. Pharmacological activation of presynaptic $\mathrm{GABA}_{\mathrm{B}}-\mathrm{Rs}$ depresses glutamate release from mossy fibers. $A$, Average non-NMDA receptormediated EPSCs evoked by mossy fiber stimulation at $1 \mathrm{~Hz}$ in control solution and in $100 \mu \mathrm{M}$ baclofen. $B$, Bath application of $100 \mu \mathrm{M}$ baclofen reduced the EPSC amplitude in a reversible manner (each point is the average of 10 EPSCs). The coefficient of variation $(C V)$ of the EPSC amplitude (bottom panel) increased during depression, indicating reduced glutamate release. $C$, Superimposed average spontaneous miniature EPSCs recorded in tetrodotoxin $(0.5 \mu \mathrm{M})$ in control solution and in the presence of $100 \mu \mathrm{M}$ baclofen. $D$, Histogram showing mean frequency of miniature EPSCs in control and in $100 \mu \mathrm{M}$ baclofen $(n=6)$.

frequencies $<10 \mathrm{~Hz}(p<0.001, n=8$; Fig. $2 B)$. However, at stimulation frequencies of $\geq 10 \mathrm{~Hz} \mathrm{GABA}_{\mathrm{B}}-\mathrm{R}$ activation had no significant effect on the amplitude of steady-state EPSC ( $p \geq 0.28$, $n=8$; Fig. $2 B$ ).

\section{Tonic GABA release, presynaptic $\mathrm{GABA}_{B}-\mathrm{R}$ activation, and GABA uptake}

In the absence of stimulation, Golgi cells in slices fire spontaneously at $3-6 \mathrm{~Hz}$ at room temperature (Dieudonne, 1998; Misra et al., 2000) and at $8 \mathrm{~Hz}$ at $37^{\circ} \mathrm{C}$ (Mitchell and Silver, 2000), which is comparable to the range of basal rates observed in vivo $(8-15 \mathrm{~Hz}$; Edgley and Lidierth, 1987; van Kan et al., 1993; Vos et al., 1999). The resulting GABA release contributes to a $\mathrm{GABA}_{\mathrm{A}}$ receptormediated tonic leak current in granule cells (Brickley et al., 1996; Tia et al., 1996; Wall and Usowicz, 1997) and can be detected as spontaneous IPSCs that are blocked by the $\mathrm{GABA}_{\mathrm{A}}$ antagonist bicuculline (data not shown). We sought to determine whether this spontaneous release of GABA from Golgi cell terminals could also 


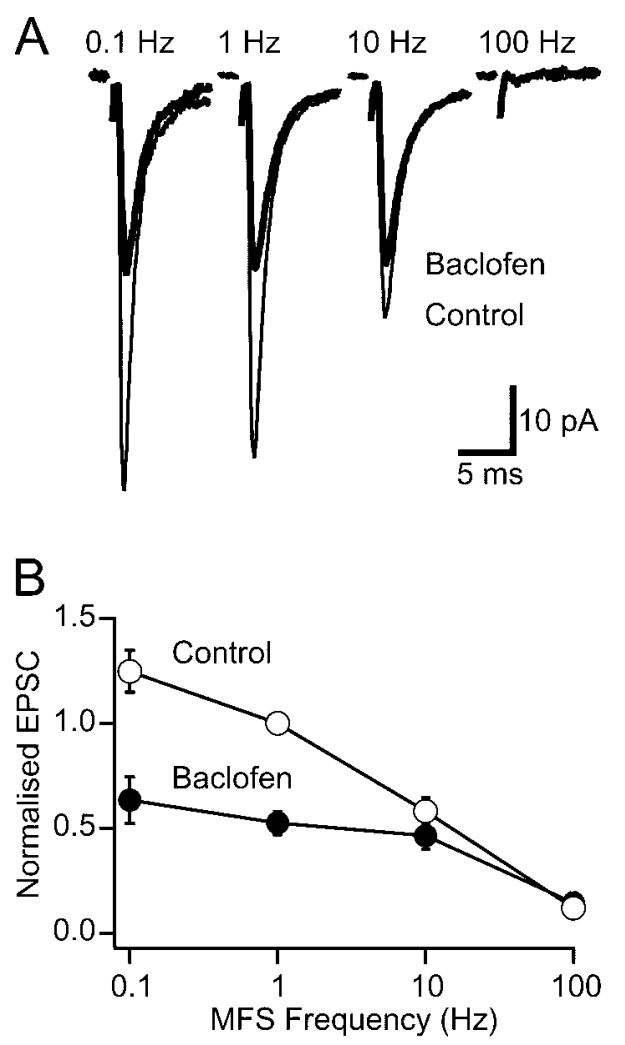

Figure 2. Frequency dependence of $\mathrm{GABA}_{\mathrm{B}}-\mathrm{R}$-mediated EPSC depression. $A$, Averaged steady-state EPSCs from the same cell recorded at different stimulation frequencies in control solution (thin trace) and in the presence of $100 \mu \mathrm{M}$ baclofen (thick trace). $B$, Steady-state frequency dependence of EPSC amplitude in control (open symbols) and in the presence of $100 \mu \mathrm{M}$ baclofen (filled symbols). The relationship shows the average of eight cells normalized to the EPSC amplitude at $1 \mathrm{~Hz}$ mossy fiber stimulation $(M F S)$ in control solution.

tonically activate $\mathrm{GABA}_{\mathrm{B}}$-Rs on mossy fibers by examining the effect of a $\mathrm{GABA}_{\mathrm{B}}$ antagonist on the EPSC amplitude. No change in the EPSC amplitude was observed during application of $500 \mu \mathrm{M}$ CGP35348 at mossy fiber stimulation frequencies between $1 \mathrm{~Hz}$ $(97 \pm 7 \%$ of control, $p=0.7, n=5$; Fig. $3 A)$ and $100 \mathrm{~Hz}(p \geq 0.3$, $n=3$; Fig. $3 B$ ) at $37^{\circ} \mathrm{C}$. These results indicate that $\mathrm{GABA}_{\mathrm{B}}-\mathrm{Rs}$ are not tonically activated at physiological temperatures.

Because tonic activation of $\mathrm{GABA}_{\mathrm{B}}$-Rs has been reported in other preparations at lower temperature (Kombian et al., 1996; Aroniadou-Anderjaska et al., 2000) (see also Parnas et al., 1999), we decided to investigate whether the lack of tonic activation at the mossy fiber could simply reflect our recording temperature. When we performed similar experiments at room temperature, the $\mathrm{GABA}_{\mathrm{B}}$ antagonist CGP35348 $(500 \mu \mathrm{M})$ potentiated EPSCs by $15 \pm 3 \%(1 \mathrm{~Hz}, p=0.01, n=4$; Fig. $3 C, D)$, suggesting that $\mathrm{GABA}_{\mathrm{B}}$-Rs tonically depress glutamate release at this temperature. What mechanism might underlie this difference in $\mathrm{GABA}_{\mathrm{B}}-\mathrm{R}$ activation at different temperatures? The most likely candidate is transmitter uptake because transporters have a high $\mathrm{Q}_{10}$ (see also Terrian et al., 1987; Wadiche and Kavanaugh, 1998). We tested this possibility by examining whether tonic $\mathrm{GABA}_{\mathrm{B}}-\mathrm{R}$ activation could be induced at physiological temperatures when GABA uptake was blocked. We used NO711 to block GABA uptake because it is not a substrate for uptake (Zeevalk and Nicklas, 1997) and thus does not induce GABA release by heteroexchange. Furthermore, NO711 specifically blocks the GAT-1 transporter, which is known to be present in cerebellar glomeruli (Itouji et al., 1996). It may also inhibit GAT-3, which is present in the glial sheath that partially surrounds glomeruli at this age (Itouji et al., 1996). Application of $50 \mu \mathrm{M}$ NO711 produced a tonic depression of the EPSC at physiological temperature $(24 \pm 5 \%, p=0.01, n=5)$ that was blocked
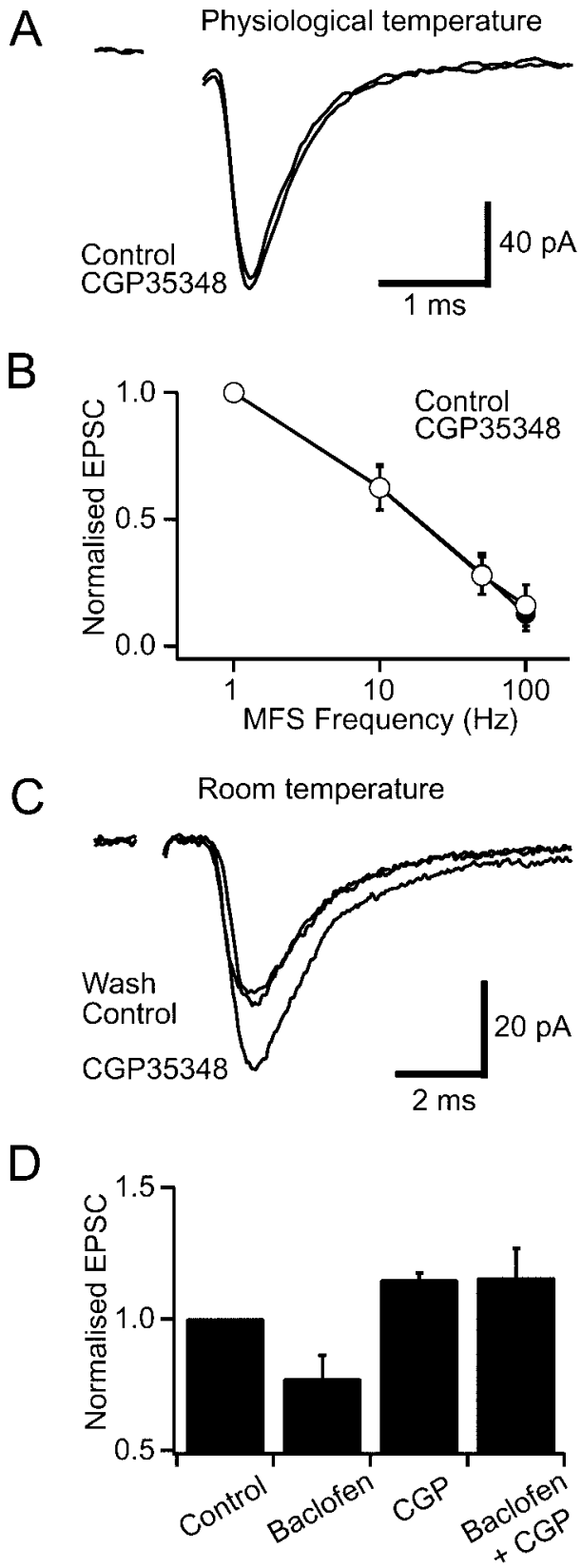

Figure 3. Tonic activation of $\mathrm{GABA}_{\mathrm{B}}$-Rs is temperature-dependent. $A$, Averaged EPSCs evoked at $1 \mathrm{~Hz}$ in control and in $500 \mu \mathrm{M}$ CGP35348 at $37^{\circ} \mathrm{C}$. B , Steady-state frequency dependence of EPSCs for control solution (open symbols) and in the presence of $500 \mu \mathrm{M}$ CGP35348 (filled symbol) at $37^{\circ} \mathrm{C}$. The relationship shows the average of three cells normalized to the 1 $\mathrm{Hz}$ EPSC amplitude in control solution. $C$, Averaged EPSCs evoked at $1 \mathrm{~Hz}$ mossy fiber stimulation $(M F S)$ in control solution and in the presence of the $\mathrm{GABA}_{\mathrm{B}}$ antagonist CGP35348 $(500 \mu \mathrm{M})$ at room temperature. D, Histogram of normalized EPSC amplitudes during control, $50 \mu \mathrm{M}$ baclofen, 500 $\mu \mathrm{M}$ CGP35348, and $500 \mu \mathrm{M}$ CGP35348 plus $50 \mu \mathrm{M}$ baclofen at room temperature $(n=4)$.

by the presence of $500 \mu \mathrm{M}$ CGP35348 ( $6 \pm 5 \%$ reduction, $p=0.22$, $n=5$; Fig. 4). These results suggest that at physiological temperature uptake maintains the basal GABA concentration below that necessary to activate presynaptic $\mathrm{GABA}_{\mathrm{B}}-\mathrm{Rs}$.

\section{Activation of $\mathrm{GABA}_{\mathrm{B}}$-Rs on mossy fibers by stimulating single Golgi cell inputs}

We examined whether $\mathrm{GABA}_{\mathrm{B}}$-Rs on mossy fiber terminals are activated at physiological temperature when GABA release is increased by stimulating single Golgi axons. We stimulated independent mossy fiber and Golgi cell inputs onto a granule cell 


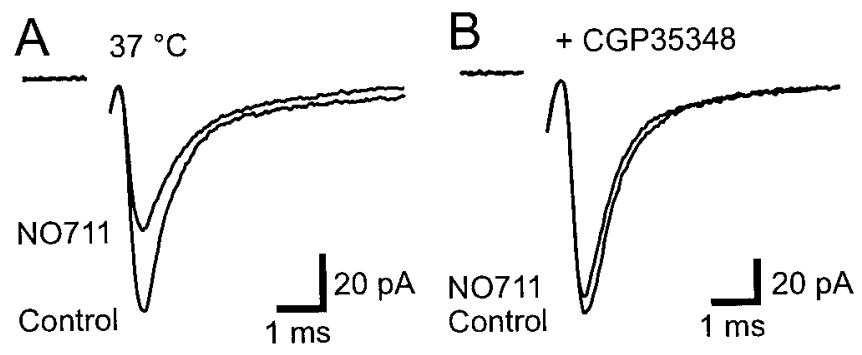

Figure 4. Inhibition of GABA uptake induces tonic activation of $\mathrm{GABA}_{\mathrm{B}}-\mathrm{Rs}$ at physiological temperature. $A$, Averaged EPSCs evoked at 1 $\mathrm{Hz}$ in control solution and in the presence of the GABA uptake blocker NO711 $(50 \mu \mathrm{M})$ at $37^{\circ} \mathrm{C}$. $B$, Averaged EPSCs evoked at $1 \mathrm{~Hz}$ in the $\mathrm{GABA}_{\mathrm{B}}$ antagonist CGP35348 $(500 \mu \mathrm{M})$ and in the presence of both $500 \mu \mathrm{M}$ CGP35348 and $50 \mu \mathrm{M}$ NO711 at $37^{\circ} \mathrm{C}$.

(illustrated in Fig. $5 A$ ) with minimal stimulation. Care was taken to ensure that stimulation of EPSCs and IPSCs was independent and that they originated from single fibers by checking that PSC amplitude was independent of stimulation voltage (Silver et al., 1996) and there were no temporally distinct components. Evoked EPSCs and monosynaptic IPSCs were distinguished by their kinetics and reversal potential (Mitchell and Silver, 2000).

The efficacy of the excitatory mossy fiber input was monitored from the amplitude of evoked non-NMDA receptor-mediated EPSCs during a stimulation train delivered at $1 \mathrm{~Hz}$ after block of ionotropic $\mathrm{GABA}_{\mathrm{A}}$ receptors with bicuculline. At the start of the train, the EPSC amplitude declined exponentially $(\tau=1.2 \mathrm{sec}$; Fig. $5 C$, dashed line) because of frequency-dependent depression. Once the EPSC amplitude had stabilized, the inhibitory Golgi cell input was stimulated for a sustained period at a frequency within the range observed in vivo during limb movement (van Kan et al., 1993), locomotion (Edgley and Lidierth, 1987), and facial stimulation (Vos et al., 1999). Stimulation of the Golgi cell input for $5 \mathrm{sec}$ at $50 \mathrm{~Hz}$ caused a marked depression in the EPSC amplitude (Fig. $5 B$ ). Although this depression was present when all experiments were averaged (Fig. 5C, top trace), it is clear from the bimodal distribution of responses (Fig. 5D) that no EPSC depression occurred in some experiments. Individual cells were therefore classified into responsive or nonresponsive groups by testing whether the EPSC amplitude was significantly different during Golgi cell stimulation (GoS), from the prestimulation amplitude (Fig. 5C; single tailed $t$ test). This approach indicated that $61 \%$ (19 of 31 cells) of granule cell recordings exhibited EPSC depression during GoS (Fig. 5D, solid line). Averaging the nonresponsive cells gave no residual response, confirming our separation procedure was effective (Fig. 5C, bottom trace).

The average time course of EPSC depression during GoS was relatively slow with the rising phase detectable after $1 \mathrm{sec}$ of Golgi cell stimulation $(p<0.001 ; n=19$; Fig. $6 A$ ). The decay of the EPSC depression could be approximated with a single exponential with a time constant of $3 \mathrm{sec}$, which is comparable to $\mathrm{GABA}_{\mathrm{B}}-\mathrm{R}$ mediated depression of EPSCs and presynaptic calcium currents at other central excitatory synapses (Isaacson et al., 1993; Pfrieger et al., 1994; Dittman and Regehr, 1997). At the peak of the response, the EPSC amplitude was depressed by $24 \pm 3 \%$ during $5 \mathrm{sec}$ GoS at $50 \mathrm{~Hz}(p<0.001, n=19$, responsive cells; Fig. $6 A)$. During depression the coefficient of variation of the EPSC increased $(0.43 \pm 0.05$ to $0.58 \pm 0.07, n=19, p=0.001$; Fig. $6 A, B)$, indicating that it was caused by a reduction in probability of glutamate release. We also tested a brief stimulation protocol ( 80 $\mathrm{Hz}$ for $250 \mathrm{msec}$ ) that mimicked the duration of Golgi cell activity during joint flexion (van Kan et al., 1993). However, this protocol produced no change in the EPSC amplitude when mossy fibers were evoked at $1 \mathrm{~Hz}(101 \pm 1 \%$ of control; $n=5 ; p=0.44)$.

If the mossy fiber axon was directly activated by the Golgi cell stimulation electrode, it is possible that the EPSC depression could be caused by "depletion" of the terminal rather than via activation of presynaptic receptors. However, examination of the traces dur-
C

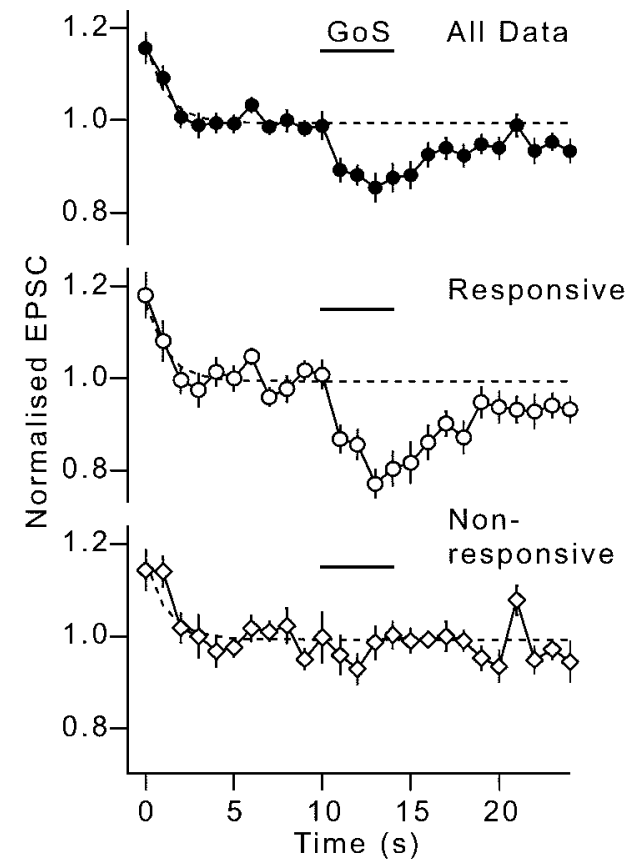

A
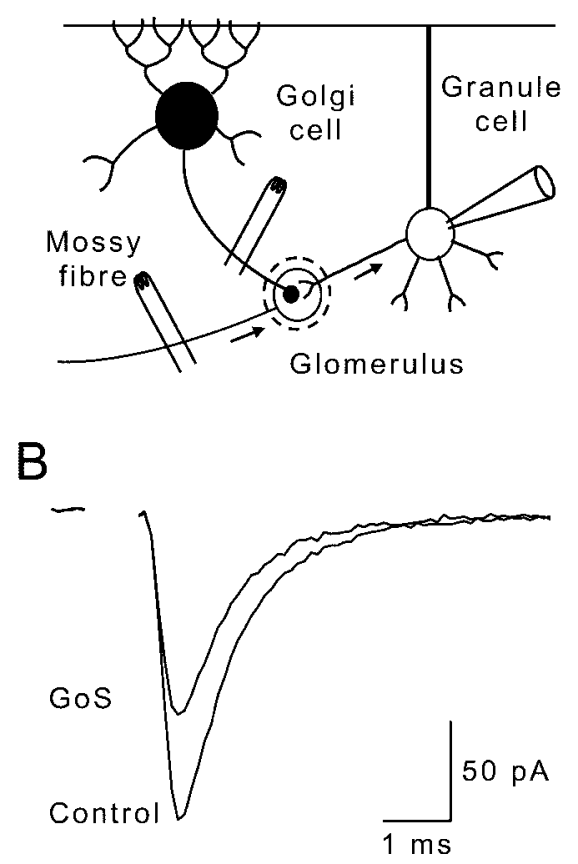

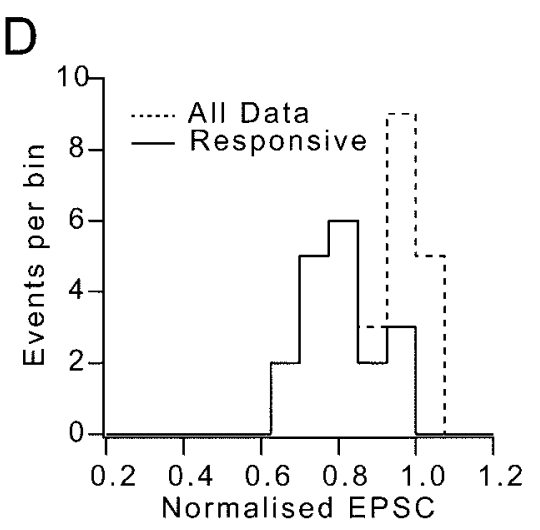

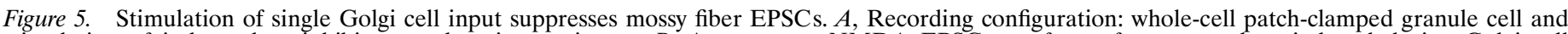

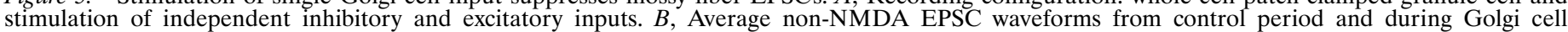

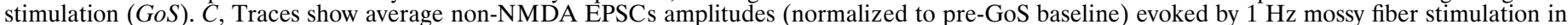

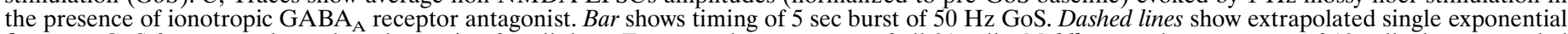

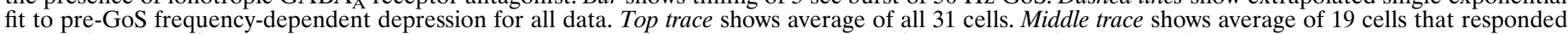

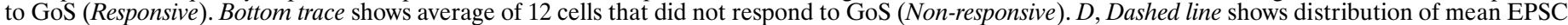
amplitudes during GoS for all cells. Solid line shows distribution for responsive cells. 
A
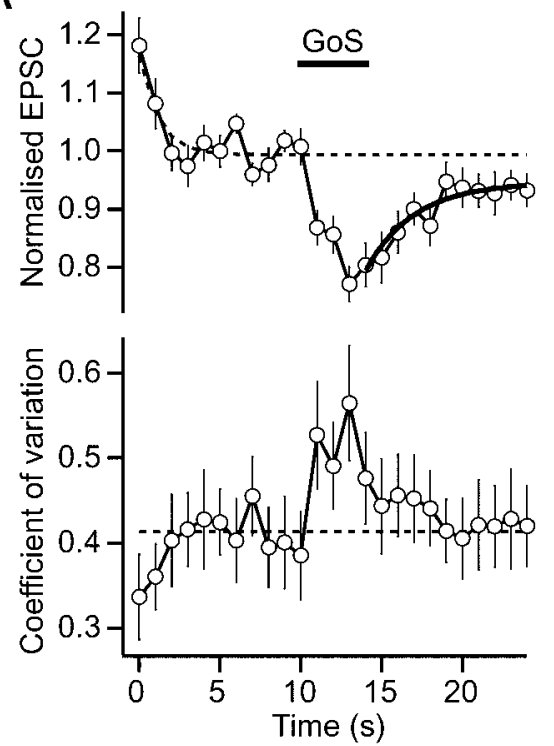

B

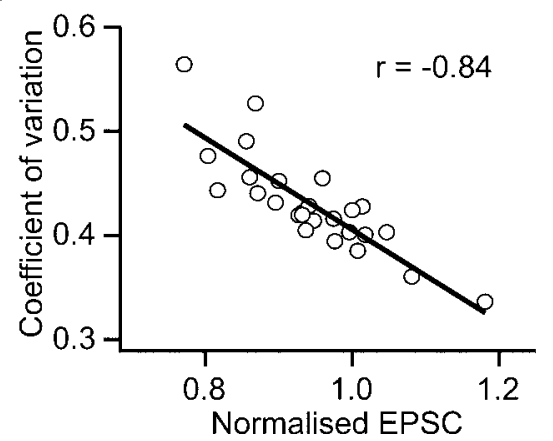

Figure 6. Golgi cell-induced suppression of mossy fiber EPSCs is presynaptic. A, Top panel, Normalized EPSC amplitudes for responsive cells during $1 \mathrm{~Hz}$ Mossy fiber stimulation in presence of ionotropic $\mathrm{GABA}_{\mathrm{A}}$ receptor antagonist (same data as Fig. 5C, middle trace). Bar shows timing of $5 \mathrm{sec}$ burst of $50 \mathrm{~Hz}$ GoS. Dashed lines show time course of frequencydependent depression from all data (Fig. 5C, top trace). Bold line shows fit of single exponential function to EPSC recovery $(\tau=3 \mathrm{sec})$. Bottom panel, CV during EPSC depression $(n=19)$. Dashed line shows pre-GoS baseline. $B$, Relationship between CV and normalized peak EPSC. Negative correlation (Spearman correlation coefficient; $r=-0.84$ ) indicates a reduction in release probability during EPSC depression.

ing Golgi cell stimulation showed that no synaptic currents were evoked in the presence of $\mathrm{GABA}_{\mathrm{A}}$ blockers (Fig. $7 A, B$ ), ruling out this possibility. Furthermore, we tested whether $\mathrm{GABA}_{\mathrm{B}}$-Rs were involved in EPSC depression by examining the effect of sustained $50 \mathrm{~Hz}$ GoS in the presence of a $\mathrm{GABA}_{\mathrm{B}}-\mathrm{R}$ antagonist. In $500 \mu \mathrm{M}$ CGP35348 the Golgi cell stimulation-induced depression of the EPSC was completely blocked $(98 \pm 6 \%$ of control, $p=0.74, n=$ 5; Fig. 7C), providing direct evidence that depression of glutamate release from the mossy fiber was caused by $\mathrm{GABA}_{\mathrm{B}}-\mathrm{R}$ activation.

To better understand the physiological role of presynaptic $\mathrm{GABA}_{\mathrm{B}}-\mathrm{Rs}$ and to test whether the frequency dependence of $\mathrm{GABA}_{\mathrm{B}}-\mathrm{R}$-mediated depression occurs during endogenous activation, we examined the effects of Golgi cell stimulation on EPSCs evoked at two different frequencies. Consistent with the frequency dependence of pharmacologically activated $\mathrm{GABA}_{\mathrm{B}}$-Rs (Fig. 2), inhibition of EPSCs during Golgi cell stimulation was significantly greater during $1 \mathrm{~Hz}$ mossy fiber stimulation $(22 \pm 6 \%)$ than during $10 \mathrm{~Hz}$ mossy fiber stimulation $(10 \pm 17 \%, p=0.02, n=4$; Fig. $8 A, B)$. Indeed, EPSCs evoked at $10 \mathrm{~Hz}$ showed no significant depression during sustained Golgi cell stimulation at $50 \mathrm{~Hz}(p=$ $0.30)$. These results demonstrate that presynaptic $\mathrm{GABA}_{\mathrm{B}}-\mathrm{Rs}$ selectively depress low-frequency mossy fiber transmission during
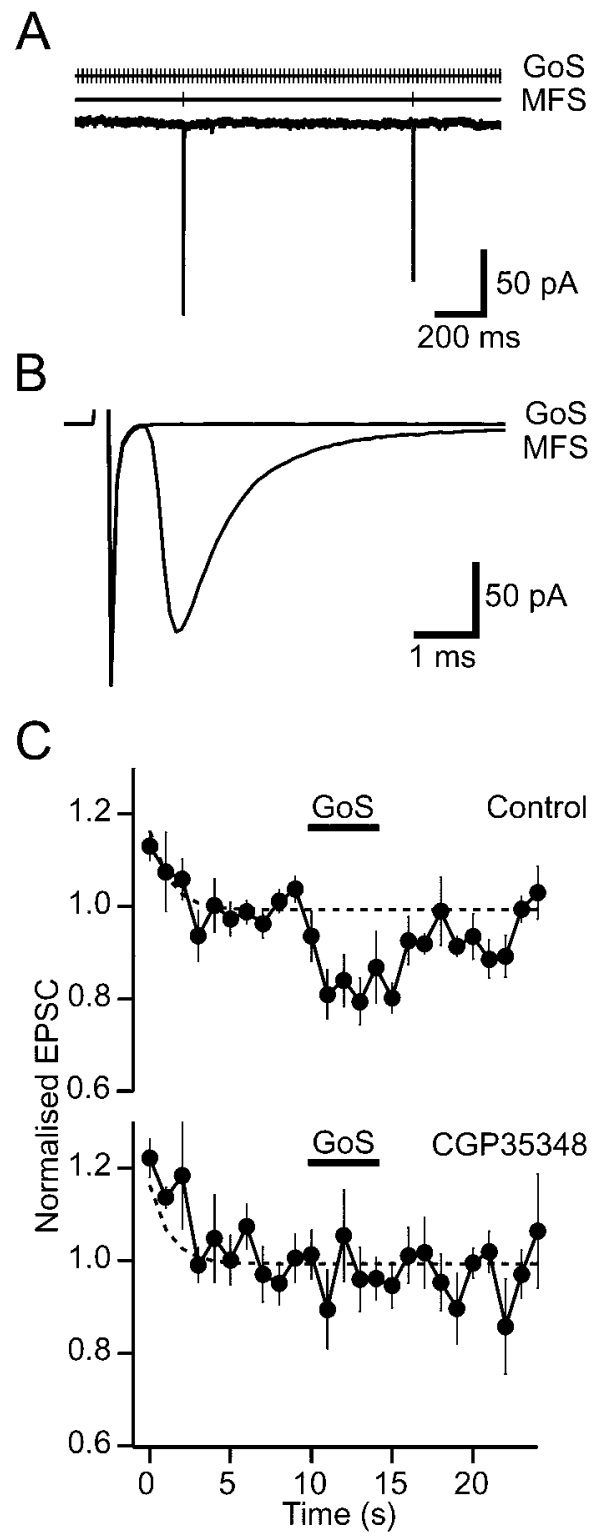

Figure 7. $\mathrm{GABA}_{\mathrm{B}}$-Rs mediate Golgi cell stimulation-induced EPSC depression. $A$, Simultaneous $50 \mathrm{~Hz}$ Golgi cell stimulation $(G o S)$ and $1 \mathrm{~Hz}$ mossy fiber stimulation $(M F S)$ in the presence of $\mathrm{GABA}_{\mathrm{A}}$ receptor blockers. EPSCs were evoked by MFS, whereas no currents were associated with the GoS. $B$, Stimulus averaged currents: MFS indicates EPSC evoked at 1 $\mathrm{Hz}$, and GoS shows IPSCs were not evoked during $50 \mathrm{~Hz}$ GoS. $C$, Normalized evoked EPSC amplitudes from the same cells before, during, and after $50 \mathrm{~Hz}$ GoS for control and in the presence of the $\mathrm{GABA}_{\mathrm{B}}-\mathrm{R}$ antagonist CGP35348 (500 $\mu \mathrm{M} ; n=5)$. Dashed lines show time course of frequency-dependent depression from all data (Fig. $5 C$, top trace).

activation by synaptically released GABA at physiological temperature.

\section{DISCUSSION}

Our results show that when individual Golgi cells fire at sustained rates above their basal level, GABA spills over onto excitatory mossy fiber terminals. GABA spillover activates presynaptic $\mathrm{GABA}_{\mathrm{B}}$ heteroreceptors at physiological temperature and depresses glutamate release in a frequency-dependent manner. This suggests that mossy fibers firing at low frequency are selectively inhibited, whereas high-frequency inputs remain unaffected.

\section{GABA spillover at physiological temperature}

Our results demonstrate that functional $\mathrm{GABA}_{\mathrm{B}}-\mathrm{Rs}$ are present on the mossy fiber terminal, consistent with immunohistochemical 


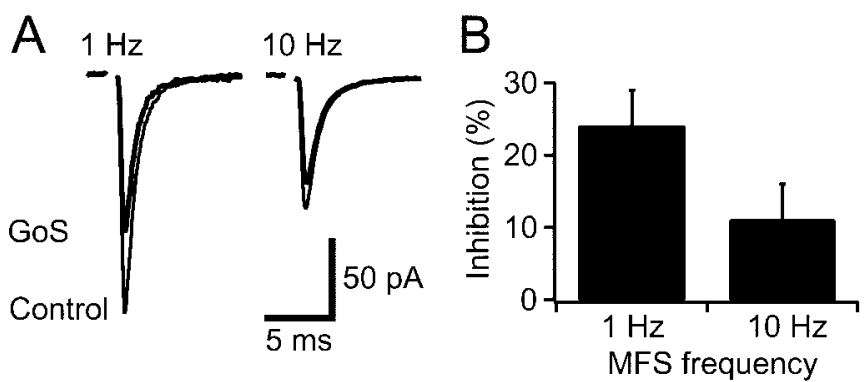

Figure 8. Physiologically activated $\mathrm{GABA}_{\mathrm{B}}$-Rs suppress low-frequency excitatory transmission. $A$, Averaged EPSCs from the same cell evoked at 1 and $10 \mathrm{~Hz}$ mossy fiber stimulation (MFS) during $50 \mathrm{~Hz}$ Golgi cell stimulation $(G o S)$. $\mathrm{GABA}_{\mathrm{B}}$-R-mediated EPSC depression was more pronounced at $1 \mathrm{~Hz}$ than at $10 \mathrm{~Hz}$. B. Histogram of mean EPSC inhibition during GoS for four cells.

evidence that shows staining for the R1b splice variant of the $\mathrm{GABA}_{\mathrm{B}}-\mathrm{R}$ in the cerebellar glomerulus (Poorkhalkali et al., 2000). Activation of $\mathrm{GABA}_{\mathrm{B}}$-Rs on mossy fiber terminals by synaptically released GABA is likely to be locally restricted within glomeruli because the concentration of GABA falls rapidly as it diff uses from the release site (for estimates for glutamate diff usion, see Barbour and Häusser, 1997; Rusakov et al., 1999), GABA transporters are present in the glomerulus (Itouji et al., 1996), and glomerular synapses are partially encapsulated by glia at this age (Hámori and Somogyi, 1983). Previous studies indicate that GABA spillover occurs in the cerebellar glomerulus. The basal level of GABA produces a postsynaptic leak conductance by tonically activating $\alpha 6$-containing GABA $_{\mathrm{A}}$ receptors (Brickley et al., 1996; Tia et al., 1996; Wall and Usowicz, 1997). These high-affinity receptors, which are located both synaptically and extrasynaptically (Nusser et al., 1998), also detect evoked GABA released from neighboring synapses, generating slow IPSCs (Rossi and Hamann, 1998). Our results showing that presynaptic $\mathrm{GABA}_{\mathrm{B}}-\mathrm{Rs}$ are activated tonically at room temperature are consistent with these previous studies and the observation that $\mathrm{GABA}_{\mathrm{B}}-\mathrm{Rs}$ are tonically active at excitatory synapses in rat supraoptic nucleus and olfactory bulb (Kombian et al., 1996; Aroniadou-Anderjaska et al., 2000). However, we find that presynaptic $\mathrm{GABA}_{\mathrm{B}}$-Rs are not tonically activated at physiological temperature $\left(\sim 37^{\circ} \mathrm{C}\right)$, suggesting GABA spillover is dependent on temperature. Several processes could underlie this temperature dependence, including changes in GABA release, modulation, or uptake. Reduced GABA release seems unlikely because Golgi cell firing rate increases with temperature (Dieudonne, 1998; Misra et al., 2000; Mitchell and Silver, 2000), and most spontaneous IPSCs in granule cells are sensitive to tetrodotoxin (Brickley et al., 1996; Wall and Usowicz 1997). A decrease in the efficacy of the modulatory mechanism is also unlikely because the degree of inhibition of the EPSC by $100 \mu \mathrm{M}$ baclofen did not change with temperature $(45 \pm 1 \%, n=3$ at room temperature; $54 \pm 5 \%$, $n=12$ at $37^{\circ} \mathrm{C} ; p=0.41$, unpaired $t$ test). In contrast, our findings that tonic activation of presynaptic $\mathrm{GABA}_{\mathrm{B}}-\mathrm{Rs}$ can be revealed at $37^{\circ} \mathrm{C}$ when uptake is inhibited, suggest that GABA uptake is likely to underlie this temperature sensitivity. Furthermore, $\mathrm{GABA}_{\mathrm{B}}-\mathrm{Rs}_{\mathrm{s}}$ can be activated at physiological temperature when Golgi cell stimulation is sustained for $\geq 1 \mathrm{sec}$, suggesting that uptake can be overcome when the amount of GABA release is increased. These results suggest that GABA spillover is more restricted at physiological temperatures than at lower temperatures because uptake is more effective at removing extracellular GABA. Temperature dependence of heterosynaptic $\mathrm{GABA}_{\mathrm{B}}-\mathrm{R}$ activation has also been observed in hippocampus (Isaacson et al., 1993), highlighting the importance of uptake when investigating the physiological role of transmitter spillover.

\section{GABA release from a single Golgi cell input activates heterosynaptic GABA G $-\mathbf{R s}$}

Several studies have established that presynaptic $\mathrm{GABA}_{\mathrm{B}}-\mathrm{Rs}$ on excitatory terminals can be activated by spillover of GABA re- leased from interneurons (Isaacson et al., 1993; Dittman and Regehr, 1997; Vogt and Nicoll, 1999; Yamada et al., 1999; AroniadouAnderjaska et al., 2000). However, it is unclear whether GABA release from a single input can activate presynaptic heteroreceptors or whether synchronous release from many axons is necessary. We have tested this by examining whether GABA release during stimulation of single inhibitory inputs onto cerebellar granule cells can activate heteroreceptors. Activation of an individual synaptic input is feasible with local extracellular stimulation in this preparation (Silver et al., 1996) because Golgi cells and mossy fibers are present at a low density in the granule cell layer (Palay and Chan-Palay, 1974), and one Golgi cell axon is thought to innervate an individual glomerulus (Eccles et al., 1967; Ito, 1984; Jakab and Hámori, 1988). Even if more than one Golgi cell axon occasionally innervates glomeruli, the minimal stimulation method will ensure only one input is activated. Furthermore, if one of the axons is not synaptically connected to the granule cell from which we recorded, slow spillover-mediated IPSCs (Rossi and Hamann, 1998) should be present when the stimulation voltage is lowered to just below the threshold of the synaptically connected axon. This was not observed. Our results therefore show that $\mathrm{GABA}_{\mathrm{B}}-\mathrm{Rs}$ on excitatory mossy fiber terminals can be activated by stimulating single inhibitory inputs at physiological temperature and frequencies observed in vivo (Edgley and Lidierth, 1987; van Kan et al., 1993; Vos et al., 1999). The EPSC depression obtained during physiological activation of $\mathrm{GABA}_{\mathrm{B}}-\mathrm{Rs}$ was significantly smaller than the depression observed with a high concentration of baclofen. Because GABA and baclofen are both full agonists (Kaupmann et al., 1997), this result suggests that $\mathrm{GABA}_{\mathrm{B}}-\mathrm{Rs}$ are only partially occupied by GABA during sustained Golgi cell firing at $50 \mathrm{~Hz}$. It is possible that the strength of $\mathrm{GABA}_{\mathrm{B}}-\mathrm{R}$ modulation changes with development because there are considerable changes in the morphology of the glomerulus between the juvenile animals studied here (P13) and mature rats (P45) (Hámori and Somogyi, 1983).

\section{Frequency dependence of $\mathrm{GABA}_{B}-\mathrm{R}$ modulation of the EPSC}

Physiological activation of presynaptic $\mathrm{GABA}_{\mathrm{B}}-\mathrm{Rs}$ reduced the EPSC by $24 \%$ (at $1 \mathrm{~Hz}$ mossy fiber stimulation) during sustained Golgi cell stimulation. At a higher mossy fiber stimulation frequency of $10 \mathrm{~Hz}$, GABA spillover did not induce significant EPSC depression, consistent with the frequency dependence observed with baclofen. Modulation of tonically firing mossy fibers by presynaptic $\mathrm{GABA}_{\mathrm{B}}-\mathrm{Rs}$ will therefore be restricted to low-frequency inputs. This contrasts with the behavior of avian auditory synapses where pharmacological activation of presynaptic $\mathrm{GABA}_{\mathrm{B}}$-Rs causes EPSC depression up to $100 \mathrm{~Hz}$ and potentiation at even high frequencies (Brenowitz et al., 1998). These differences may reflect functional heterogeneity in $\mathrm{GABA}_{\mathrm{B}}$ modulation at different central synapses.

$\mathrm{GABA}_{\mathrm{B}}$-Rs are thought to inhibit glutamate release via G-protein-mediated downregulation of presynaptic calcium currents (Dittman and Regehr, 1996; Isaacson, 1998; Takahashi et al., 1998) and of the release process (Capogna et al., 1996; Dittman and Regehr, 1996). If $\mathrm{GABA}_{\mathrm{B}}$-Rs simply modulate the initial release probability $\left(P_{\mathrm{r} 1}\right)$, then the frequency dependence may arise from the release process in a manner analogous to that observed after cortical long-term plasticity (Markram and Tsodyks, 1996). Simple vesicular depletion models predict that as stimulation frequency is increased, the release probability becomes dependent on the rate of recovery of the readily releasable pool and independent of the vesicle fusion rate and thus $P_{\mathrm{r} 1}$ (Abbott et al., 1997; Tsodyks and Markram 1997; Matveev and Wang 2000). If this mechanism contributes to other forms of presynaptic modulation, differences in the frequency dependence of $\mathrm{GABA}_{\mathrm{B}}-\mathrm{R}$ modulation of excitatory mossy fibers and mGluR modulation of inhibitory Golgi cells (Mitchell and Silver, 2000) could simply reflect the values of $P_{\mathrm{r} 1}$ and the rate of recovery of the release sites at these two synapses. Another mechanism that might underlie the frequency dependence include voltage-dependent relief of G-protein inhibition (Bean, 
1989; Brody et al., 1997; Dolphin, 1998) at higher mossy fiber firing frequencies because bursts of action potential waveforms relieve inhibition of calcium channels in human embryonic kidney 293 cells (Brody et al., 1997). Activation of mGluRs on the Golgi cell terminals during mossy fiber stimulation (Mitchell and Silver, 2000) might also influence the frequency dependence of physiologically activated $\mathrm{GABA}_{\mathrm{B}}-\mathrm{R}$-mediated EPSC depression by reducing GABA release at higher mossy fiber stimulation frequencies. However, this mechanism is not likely to be limiting, because the frequency dependence of EPSC depression observed with GABA spillover and baclofen was similar. Last, $\mathrm{GABA}_{\mathrm{B}}-\mathrm{R}$-mediated depression could be occluded by autoreceptor-mediated EPSC depression, which is also likely to be frequency-dependent. Although investigation of the precise mechanisms underlying the frequency dependence $\mathrm{GABA}_{\mathrm{B}}$-Rs is beyond the scope of this study, characterization of the steady-state frequency dependence of EPSCs during $\mathrm{GABA}_{\mathrm{B}}-\mathrm{R}$ activation is relevant for understanding transmission at mossy fiber inputs that fire relatively regularly, as observed for "tonic" inputs encoding joint angle (van Kan et al., 1993). Furthermore, our steady-state data provide the basis for a detailed investigation of the effects of $\mathrm{GABA}_{\mathrm{B}}-\mathrm{R}$ modulation on short-term plasticity by determining the level of $G A B A_{B}-R$ activation under physiological conditions.

\section{Bidirectional spillover of transmitter in the glomerulus: implications for information processing in the cerebellar cortex}

Spillover of GABA onto $\mathrm{GABA}_{\mathrm{B}}-\mathrm{Rs}$ on mossy fiber terminals shown here mirrors glutamate spillover onto mGluRs on Golgi cell axon terminals (Mitchell and Silver, 2000). The two components of these bidirectional spillover-mediated processes have opposite yet complementary effects in terms of information processing. Activation of mGluRs on Golgi cell terminals by glutamate has an excitatory action by suppressing GABA release onto granule cells. Because the size of this effect depends on the firing frequency of the excitatory input, it will tend to boost the postsynaptic effects of mossy fibers firing at higher rates and may compensate for frequency-dependent depression of the EPSC. In contrast, activation of $\mathrm{GABA}_{\mathrm{B}}-\mathrm{Rs}$ on mossy fibers by GABA spillover depresses low-frequency excitatory inputs, making these inputs less effective. These two spillover-mediated presynaptic mechanisms are likely to be effective under different network conditions: the mGluR system will be most effective when the Golgi cell firing rate is low, whereas the $\mathrm{GABA}_{\mathrm{B}}$ system will be most effective when it is high. The spatial characteristics of the mGluR and $\mathrm{GABA}_{\mathrm{B}}$-R-mediated effects are also different. GABA $-\mathrm{B}$-mediated inhibition of the EPSC is set by the Golgi cell axonal arbor, which contacts $\sim 5000$ granule cells in the region (Ito, 1984), whereas mGluR-mediated Golgi cell disinhibition is set by the distribution of the $\sim 20$ glomeruli (per folium) associated with an individual mossy fiber (Eccles et al., 1967; Ito, 1984). Our results suggest that presynaptic heteroreceptors in the glomerulus modulate the efficacy of synaptic input onto granule cells over a range of network activity and play a role in processing sensory information as it enters the cerebellar cortex.

\section{REFERENCES}

Abbott LF, Varela JA, Sen K, Nelson SB (1997) Synaptic depression and cortical gain control. Science 275:220-224.

Aroniadou-Anderjaska V, Zhou F-M, Priest CA, Ennis M, Shipley MT (2000) Tonic and synaptically evoked presynaptic inhibition of sensory input to the rat olfactory bulb via GABAB heteroreceptors. J Neurophysiol 84:1194-1203.

Barbour B, Häusser M (1997) Intersynaptic diffusion of neurotransmitter. Trends Neurosci 20:377-384.

Bean BP (1989) Neurotransmitter inhibition of neuronal calcium currents by changes in channel voltage dependence. Nature 340:153-156.

Brenowitz S, David J, Trussell L (1998) Enhancement of synaptic efficacy by presynaptic GABA(B) receptors. Neuron 20:135-141.

Brickley SG, Cull-Candy SG, Farrant M (1996) Development of a tonic form of synaptic inhibition in rat cerebellar granule cells resulting from persistent activation of GABAA receptors. J Physiol (Lond) 497:753-759.

Brody DL, Yue DT (2000) Relief of G-protein inhibition of calcium chan- nels and short-term synaptic facilitation in cultured hippocampal neurons. J Neurosci 20:889-898.

Brody DL, Patil PG, Mulle JG, Snutch TP, Yue DT (1997) Bursts of action potential waveforms relieve G-protein inhibition of recombinant $P / Q-$ type Ca2 + channels in HEK 293 cells. J Physiol (Lond ) 499:637-644.

Capogna M, Gahwiler BH, Thompson SM (1996) Presynaptic inhibition of calcium-dependent and -independent release elicited with ionomycin, gadolinium, and alpha-latrotoxin in the hippocampus. J Neurophysiol 75:2017-2028.

Clements JD, Bekkers JM (1997) Detection of spontaneous synaptic events with an optimally scaled template. Biophys J 73:220-229.

Davies CH, Starkey SJ, Pozza MF, Collingridge GL (1991) GABA autoreceptors regulate the induction of LTP. Nature 349:609-611.

Deisz RA, Prince DA (1989) Frequency-dependent depression of inhibition in guinea-pig neocortex in vitro by GABAB receptor feed-back on GABA release. J Physiol (Lond) 412:513-541.

Dieudonne S (1998) Submillisecond kinetics and low efficacy of parallel fibre-Golgi cell synaptic currents in the rat cerebellum. J Physiol (Lond) 510:845-866.

Dittman JS, Regehr WG (1996) Contributions of calcium-dependent and calcium-independent mechanisms to presynaptic inhibition at a cerebellar synapse. J Neurosci 16:1623-1633.

Dittman JS, Regehr WG (1997) Mechanism and kinetics of heterosynaptic depression at a cerebellar synapse. J Neurosci 17:9048-9059.

Dolphin AC (1998) Mechanisms of modulation of voltage-dependent calcium channels by $\mathrm{G}$ proteins. J Physiol (Lond) 506:3-11.

Eccles JC, Ito M, Szentagothai J (1967) The cerebellum as a neuronal machine. Heidelberg: Springer.

Edgley SA, Lidierth M (1987) The discharges of cerebellar Golgi cells during locomotion in the cat. J Physiol (Lond) 392:315-332.

Hámori J, Somogyi J (1983) Differentiation of cerebellar mossy fiber synapses in the rat: a quantitative electron microscope study. J Comp Neurol 220:365-377.

Isaacson JS (1998) GABAB-R-mediated modulation of presynaptic currents and excitatory transmission at a fast central synapse. $\mathrm{J}$ Neurophysiol 80:1571-1576.

Isaacson JS, Solis JM, Nicoll RA (1993) Local and diff use synaptic actions of GABA in the hippocampus. Neuron 10:165-175.

Ito M (1984) The cerebellum and neural control. New York: Raven.

Itouji A, Sakai N, Tanaka C, Saito N (1996) Neuronal and glial localization of two GABA transporters (GAT1 and GAT3) in the rat cerebellum. Brain Res Mol Brain Res 37:309-316.

Jakab RL, Hámori J (1988) Quantitative morphology and synaptology of cerebellar glomeruli in the rat. Anat Embryol 179:81-88.

Kaupmann K, Huggel K, Heid J, Flor PJ, Bischoff S, Mickel SJ, McMaster G, Angst C, Bittiger H, Froestl W, Bettler B (1997) Expression cloning of GABA(B) receptors uncovers similarity to metabotropic glutamate receptors. Nature 386:239-246.

Kombian SB, Zidichouski JA, Pittman QJ (1996) GABAB receptors presynaptically modulate excitatory synaptic transmission in the rat supraoptic nucleus in vitro. J Neurophysiol 76:1166-1179.

Kreitzer AC, Regehr WG (2000) Modulation of transmission during trains at a cerebellar synapse. J Neurosci 20:1348-1357.

Markram H, Tsodyks M (1996) Redistribution of synaptic efficacy between neocortical pyramidal neurons. Nature 382:807-810.

Matveev V, Wang XJ (2000) Implications of all-or-none synaptic transmission and short-term depression beyond vesicle depletion: a computational study. J Neurosci 20:1575-1588.

Misra C, Brickley SG, Farrant M, Cull-Candy SG (2000) Identification of subunits contributing to synaptic and extrasynaptic NMDA receptors in Golgi cells of the rat cerebellum. J Physiol (Lond ) 524:147-162.

Mitchell SJ, Silver RA (2000) Glutamate spillover suppresses inhibition by activating presynaptic mGluRs. Nature 404:498-502.

Nusser Z, Sieghart W, Somogyi P (1998) Segregation of different GABAA receptors to synaptic and extrasynaptic membranes of cerebellar granule cells. J Neurosci 18:1693-1703.

Palay SL, Chan-Palay V (1974) Cerebellar cortex cytology and organization. Berlin: Springer.

Parnas I, Rashkovan G, Ong J, Kerr DI (1999) Tonic activation of presynaptic GABAB receptors in the opener neuromuscular junction of crayfish. J Neurophysiol 81:1184-1191.

Pfrieger FW, Gottmann K, Lux HD (1994) Kinetics of GABAB receptormediated inhibition of calcium currents and excitatory synaptic transmission in hippocampal neurons in vitro. Neuron 12:97-107.

Poorkhalkali N, Juneblad K, Jonsson AC, Lindberg M, Karlsson O, Wallbrandt P, Ekstrand J, Lehmann A (2000) Immunocytochemical distribution of the GABA(B) receptor splice variants GABA(B) R1a and R1b in the rat CNS and dorsal root ganglia. Anat Embryol (Berl ) 201:1-13.

Rossi DJ, Hamann M (1998) Spillover-mediated transmission at inhibitory synapses promoted by high affinity $\alpha 6$ subunit GABAA receptors and glomerular geometry. Neuron 20:783-795.

Rusakov DA, Kullmann DM, Stewart MG (1999) Hippocampal synapses: do they talk to their neighbours? Trends Neurosci 22:382-388.

Shepherd GM (1998) Synaptic organisation of the brain, Ed 4. Oxford: Oxford UP.

Silver RA, Cull-Candy SG, Takahashi T (1996) Non-NMDA glutamate 
receptor occupancy and open probability at a rat cerebellar synapse with single and multiple release sites. J Physiol (Lond) 494:231-250.

Silver RA, Momiyama A, Cull-Candy SG (1998) Locus of frequencydependent depression identified with multiple-probability fluctuation analysis at rat climbing fibre-Purkinje cell synapses. J Physiol (Lond) 510:881-902.

Takahashi T, Kajikawa Y, Tsujimoto T (1998) G-Protein-coupled modulation of presynaptic calcium currents and transmitter release by a GABAB receptor. J Neurosci 18:3138-3146.

Terrian DM, Green CL, Dorman RV, Wu PH (1987) Uptake, exchange, and release of GABA by cerebellar glomeruli. Neurochem Res 12:399-408

Tia S, Wang JF, Kotchabhakdi N, Vicini S (1996) Developmental changes of inhibitory synaptic currents in cerebellar granule neurons: role of GABAA receptor $\alpha 6$ subunit. J Neurosci 16:3630-3640.

Tsodyks MV, Markram H (1997) The neural code between neocortical pyramidal neurons depends on neurotransmitter release probability. Proc Natl Acad Sci USA 94:719-723.

van Kan PL, Gibson AR, Houk JC (1993) Movement-related inputs to intermediate cerebellum of monkeys. J Neurophysiol 69:74-94.
Vogt KE, Nicoll RA (1999) Glutamate and gamma-aminobutyric acid mediate a heterosynaptic depression at mossy fiber synapses in the hippocampus. Proc Natl Acad Sci USA 96:1118-1122.

Vos BP, Volny-Luraghi A, De Schutter E (1999) Cerebellar Golgi cells in the rat: receptive fields and timing of responses to facial stimulation. Eur J Neurosci 11:2621-2634.

Wadiche JI, Kavanaugh MP (1998) Macroscopic and microscopic properties of a cloned glutamate transporter/chloride channel. J Neurosci 18:7650-7661.

Wall MJ, Usowicz MM (1997) Development of action potentialdependent and independent spontaneous GABAA receptor-mediated currents in granule cells of postnatal rat cerebellum. Eur J Neurosci 9:533-548.

Yamada J, Saitow F, Satake S, Kiyohara T, Konishi S (1999) GABA(B) receptor-mediated presynaptic inhibition of glutamatergic and GABAergic transmission in the basolateral amygdala. Neuropharmacology 38:1743-1753.

Zeevalk GD, Nicklas WJ (1997) Activity at the GABA transporter contributes to acute cellular swelling produced by metabolic impairment in retina. Vision Res 37:3463-3470. 